\title{
Malignant gastric lymphoma with spontaneous perforation
}

\author{
Satoko Shimada, Tokichi Gen, Hiroyuki Okamoto \\ Department of General Surgery, JA Toride Medical Centre, Toride-shi, Japan \\ Correspondence to Dr Satoko Shimada, stomiya@juntendo.ac.jp
}

\begin{abstract}
Summary
Malignant gastric lymphoma, accounting only for $1 \%$ of primary gastric carcinoma, is usually a diffuse large B-cell lymphoma. Toyota et al reported that $37 \%$ of gastric perforations involved malignancy, generally gastric carcinoma. Fukuda et al found that less than $5 \%$ of malignant gastric lymphomas perforate. While it is relatively well known that perforations often take place during chemotherapy, they are rare in patients not receiving chemotherapy. To our knowledge, spontaneous perforation is rare in gastric malignant lymphoma, having been reported in the Japanese literature only 26 times, including this case, in the last 25 years.
\end{abstract}

\section{BACKGROUND}

Today, the standard treatment for aggressive gastric lymphoma has shifted from surgery to chemotherapy combined with rituximab; that is, CHOP-R. ${ }^{1}$ There is as yet no established treatment strategy for gastric malignant lymphoma. ${ }^{2}$ Its merits emphasise that outcomes of malignant gastric lymphoma with spontaneous perforation was poor (less than 2 years) compared to those without perforation. ${ }^{3}$ There were two reports in 1983 and 1993 mentioning the frequency of occurrence of spontaneous perforation having been $4.0 \%$ and $4.2 \%$, respectively. ${ }^{4}$ However, Law et al ${ }^{6}$ did not find any spontaneous perforations in their 61 cases of patients with malignant gastric lymphoma. Patients in the Western country reached their peak of vulnerability to spontaneous perforation in their 60s; however, the incidence seen at younger ages, mean 56 years old in Japan. It was worldwide that men were more vulnerable to it than that of women. It was only our case that patient was ready for her scheduled operation which was 2 days prior, when the perforation occurred. Therefore, the choice of treatment including surgery should be carefully deliberated.

\section{CASE PRESENTATION}

An 85-year-old woman, whose medical, social and family histories were unremarkable, presented with anorexia and weight loss (a $6 \mathrm{~kg}$ decrease in the preceding 6 months). The patient also began to suffer from a lower back pain around on 25 March 2008. She consulted a neighbourhood doctor on 27 March.

\section{INVESTIGATIONS}

A subsequent endoscopic investigation identified a small number of ulcerations at the pyloric antrum of the stomach and pyloric stenosis. She was thus hospitalised, fasted and treated with fluids and proton pump inhibitors. Although her condition improved, endoscopic biopsy revealed that she had diffuse large B-cell lymphoma (DLBCL). She was discharged from the hospital in preparation of her treatment.

Status on admission in our hospital (3 June 2008): height $147 \mathrm{~cm}$, weight $37 \mathrm{~kg}$, temperature $36.6^{\circ} \mathrm{C}$, blood pressure $124 / 68 \mathrm{~mm} \mathrm{Hg}$. She was able to eat a small amount of food. There was a firm, immobile, clearly bounded and egg-sized lump at the left lower abdomen.

Lab data below showed that she had anaemia, increased lactate dehydrogenase (LDH) and interleukin (IL)-2 receptor; leucocytes $3990 / \mu \mathrm{l}$, haemoglobin $(\mathrm{Hb}) 7.5 \mathrm{~g} / \mathrm{dl}$, platelets $44.1 \times 10 / \mu \mathrm{l}$, C reactive protein $0.37 \mathrm{mg} / \mathrm{dl}, \mathrm{LDH}$ $511 \mathrm{IU} / \mathrm{l}$, IL-2 receptor $965 \mathrm{U} / \mathrm{ml}$.

\section{DIFFERENTIAL DIAGNOSIS}

Gastric mucosa-associated lymphoid tissue lymphoma, Burkitt lymphoma, Hodgkin's lymphoma, peptic ulcer, gastric carcinoma, small lymphocytic lymphoma, mantle cell lymphoma, follicular lymphoma, GIST and melanoma.

\section{TREATMENT}

She was informed of her treatment choices, namely, chemotherapy plus radiotherapy, chemotherapy plus rituximab or surgery alone. She visited the gastroenterological outpatient department of our hospital for a second opinion on 22 April. Chemotherapy plus rituximab was recommended. However, she returned to our clinic on 20 May for yet another opinion. She was subsequently admitted to our ward on 3 June, scheduled to undergo surgery on 9 June. A central venous line was placed on 5 June. She was anaemic $(\mathrm{Hb} 7.5 \mathrm{~g} / \mathrm{dl})$, so she received 2 units of concentrated red blood cells over the next 2 days.

\section{OUTCOME AND FOLLOW-UP}

On 7 June, she complained of abdominal pain and was awake until 5:00 at the nurse station owing to anxiety and sleeplessness. Her temperature rose to $38.6^{\circ} \mathrm{C}$. Emergency CT showed intraperitoneal free air under the diaphragm bilaterally, under the parietal peritoneum and within the portal hepatis, and a large amount of ascites. Malignant gastric lymphoma with spontaneous perforation and panperitonitis was diagnosed. The following emergency operations were performed: total gastrectomy, cholecystectomy and intraperitoneal drainage (figure 1). Upon incision of the abdomen, purulent ascites was observed. The entire stomach was sclerotic, with a $30 \mathrm{~mm}$ perforation on the 


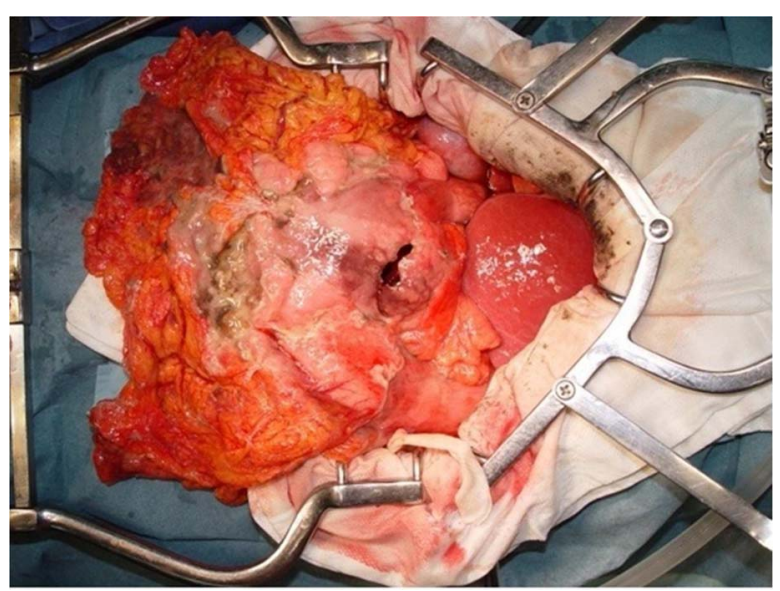

Figure 1 The entire stomach, with a $30 \mathrm{~mm}$ perforation on the large ulcerated tumour of the anterior pyloric antrum, is shown.

large ulcerated tumour of the anterior pyloric antrum. The ulcerated tumours measuring $65 \times 60 \mathrm{~mm}$ and $90 \times 85 \mathrm{~mm}$ were located at the anterior and posterior pyloric antrum, respectively (figure 2). Lymph nodes around the stomach were elastic and enlarged.

Pathological results reported ulcerative type with focal perforations, infiltrating the serosa. H\&E staining showed diffuse, B-cell type and large-cell lymphoma. Immunohistochemical staining showed the tumour to be CD20 and CD79a positive, but CD3 and cyclin D1 negative (figure 3). The number of metastatic lymph nodes was 31/54. Dissemination to the major omentum was confirmed. The Lugano classification was considered to be Stage II1.

She recovered from the operation uneventfully and was discharged from the hospital 25 days postoperatively. She refused to undergo adjuvant chemotherapy and ascites recurred 4.5 months after surgery. She again refused any treatment then. She only began to take an opioid as a palliative care 6 months after surgery. The patient died 6.5 months after surgery.

\section{DISCUSSION}

Tanaka et al reported on 24 cases of malignant lymphoma with spontaneous perforation. Their 24 cases plus our

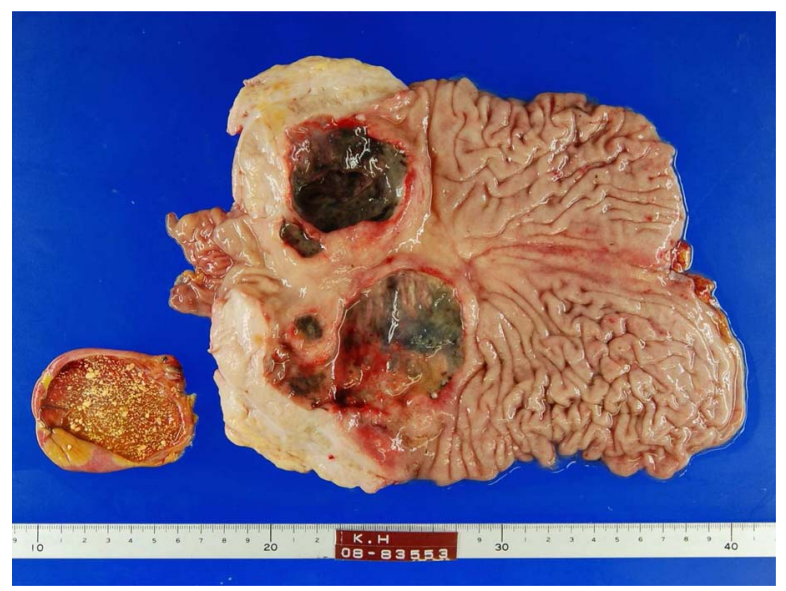

Figure 2 The gallbladder, ulcerated tumours measuring $65 \times 60 \mathrm{~mm}$ and $90 \times 85 \mathrm{~mm}$ located at the anterior and posterior of pyloric antrum, respectively, are shown.

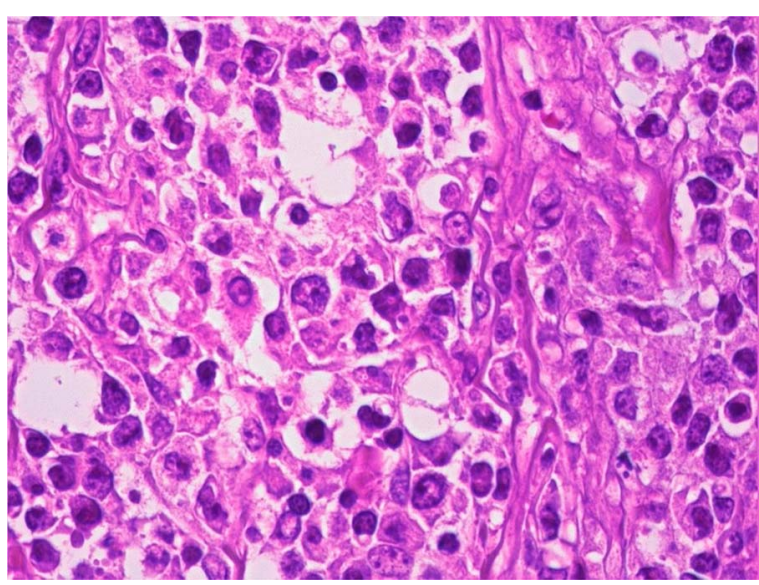

Figure 3 Pathological investigation: H\&E staining showed diffuse, B-cell type, large-cell lymphoma. Magnification: $\times 40$.

present case and an additional case reported in the meantime are presented in table 1 . Perforation occurred in the body of the stomach in 15 cases and in the pylorus in 13 cases. Tumour sizes ranged from 15 to $250 \mathrm{~mm}$, mean $67.6 \mathrm{~mm}$. There were eight cases of excavated type and six of ulcerative type according to Sano's classification, ${ }^{7}$ suggesting tumours with ulceration to be common in perforation cases. Pathologically, diffuse large cell lymphoma was seen in 12 cases. According to Mitsunaga, pathology of malignant lymphoma often exists in conjunction with other tumour types. Large, ulcerative-type tumours are reportedly more likely to perforate. ${ }^{8}$

Tanaka et al also noted that pretreatment diagnosis is rare, occurring in only 6 of 24 cases. In the usual course of events, as soon as the diagnosis is made, treatment starts. It is widely known that perforation occasionally occurs in patients receiving chemotherapy. In contrast, spontaneous perforation of malignant gastric lymphoma is rare. The present patient was 85 years old and refused chemotherapy. However, the main tumour was $90 \mathrm{~mm}$ in size, raising the possibility of perforation regardless of whether chemotherapy was being administered.

Today, the standard treatment for aggressive gastric lymphoma has shifted from surgery to chemotherapy combined with rituximab; that is, CHOP-R. Aviles et al reported the 10-year survival rate of 589 patients with early stage primary gastric DLBCL, according to choice of treatment. The patients were divided into four treatment groups: surgery, surgery plus radiation, surgery plus chemotherapy and $\mathrm{CHOP}$. The 10-year survival rates were $28 \%, 23 \%$, $82 \%$ and $92 \%$, respectively. ${ }^{9}$ It is somewhat surprising that patients who chose chemotherapy alone achieved the best result. Nevertheless, a simple comparison of results between Japan and Western nations is problematic. This is partly due to differences in the standard of management of gastric carcinoma. Gastric carcinoma is common in Japan, where the surgical death rate is less than $2 \%$, whereas in Western nations, the rate is substantially higher partly because of D2 gastrectomy not having become standard yet. Nakamura et al compared the survival rate of patients choosing surgery to those selecting chemotherapy or radiotherapy, and found differences did not reach statistical significance. There is as 
Table 1 Twenty-six reported cases of malignant gastric lymphoma with spontaneous perforation ${ }^{11-28}$

\begin{tabular}{|c|c|c|c|c|c|c|c|c|c|c|}
\hline & Age & Tumour size & Size of perforation & Outcome & Sex & Location & $\begin{array}{l}\text { Sano's } \\
\text { class }\end{array}$ & LSG class & Operation & $\begin{array}{l}\text { Adjuvant } \\
\text { chemotherapy }\end{array}$ \\
\hline 1985 Kanzaki & 42 & $3.2 \times 3.2 \mathrm{~cm}$ & $0.5 \mathrm{~cm}$ & $>18$ & $M$ & $M$ & & Burkitt & & VEMP \\
\hline 1987 Oda & 43 & & $6 \mathrm{~mm}$ & $>2$ & $\mathrm{M}$ & $\mathrm{L}$ & & Non-Hodgkin's & Subtotal & \\
\hline 1989 Takeda & 85 & & & & & & & DLBC & & \\
\hline 1990 Yamaguchi & 57 & & & & & & & & Subtotal & Chemotherapy \\
\hline 1992 Ando & 22 & $1.5 \times 1.4 \mathrm{~cm}$ & & $>30$ & $\mathrm{M}$ & $\mathrm{M}$ & & DMBC & Subtotal & $\mathrm{CHO}(\mathrm{P})$ \\
\hline 1992 Yanagi & 65 & $18.5 \times 10 \mathrm{~cm}$ & $\begin{array}{l}2 \times 2.5 \mathrm{~cm} \\
4.5 \times 2.5 \mathrm{~cm}\end{array}$ & $>10$ & $M$ & L & & DLBC & & $\mathrm{CHOP}$ \\
\hline 1994 Shinjyo & 14 & & $9 \times 4 \mathrm{~mm}$ & & $\mathrm{~F}$ & $\mathrm{~L}$ & & & Subtotal & Chemotherapy \\
\hline 1996 Uni & 45 & & $5 \mathrm{~mm}$ & & $\mathrm{~F}$ & $\mathrm{M}$ & & DMBC & Subtotal & VEPA \\
\hline 1996 Mori & 87 & & & & $\mathrm{~F}$ & $\mathrm{~L}$ & & DMBC & Subtotal & \\
\hline 1997 Ono & 43 & $25 \mathrm{~cm}$ & $2 \mathrm{~cm}$ & $>3$ & $\mathrm{~F}$ & $\mathrm{~L}$ & & DLBC & Closure & $\mathrm{CHOP}$ \\
\hline 1997 Shiomi & 71 & $15 \times 13 \mathrm{~cm}$ & $2 \mathrm{~cm}$ & 7 & $M$ & $M$ & Excarvated & DLBC & Total & THP-COP \\
\hline 1997 Banya & 43 & $25 \mathrm{~cm}$ & $2 \mathrm{~cm}$ & & $\mathrm{M}$ & $\mathrm{L}$ & & DLBC & Closure & $\mathrm{CHOP}$ \\
\hline 1997 Fukuda & 45 & $8 \times 9 \mathrm{~cm}$ & $7 \mathrm{~mm}$ & $>25$ & $\mathrm{M}$ & $\mathrm{M}$ & & DMBC & Subtotal & VEPA \\
\hline 1998 Yanagisawa & 72 & $7.5 \times 6.0 \mathrm{~cm}$ & & $>15$ & $\mathrm{M}$ & $\mathrm{M}$ & & DLBC & Subtotal & CHOP \\
\hline 1998 Yanagisawa & 26 & $6.5 \times 4.5$ & & $>14$ & M & $\mathrm{M}$ & & DLBC & Subtotal & CHOP \\
\hline 1998 Housui & 58 & & $8 \mathrm{~mm}$ & & $\mathrm{~F}$ & & & DLBC & Total & Chemotherapy \\
\hline 1999 Miyamoto & 46 & $3.0 \times 2.8 \mathrm{~cm}$ & $6 \mathrm{~mm}$ & $>62$ & M & $\mathrm{L}$ & & MALT & & \\
\hline 2000 Yabuki & 53 & $8 \times 6 \mathrm{~cm}$ & $1.0 \times 0.5 \mathrm{~cm}$ & $>28$ & $\mathrm{M}$ & $\mathrm{M}$ & & DMBC & Subtotal & $\mathrm{CHOP}$ \\
\hline 2001 Hoshino & 59 & $\mathrm{Nk}$ & $3 \mathrm{~mm}$ & & $\mathrm{~F}$ & $M \sim L$ & & DMBC & Total & Chemotherapy \\
\hline 2002 Yokoyama & 64 & & $10 \mathrm{~mm}$ & & & $\mathrm{M}$ & & DLBC & Subtotal & $\mathrm{CHOP}$ \\
\hline 2005 Mori & 65 & $3 \times 3 \mathrm{~cm}$ & $5 \mathrm{~mm}$ & 2 & $\mathrm{~F}$ & $\mathrm{M}$ & & DMBC & Total & $\mathrm{CHOP}$ \\
\hline 2006 Tanaka & 65 & $10 \mathrm{~cm}$ & & & & & & & Total & \\
\hline 2007 Tanaka & 84 & $9 \times 8 \mathrm{~cm}$ & $1 \mathrm{~cm}$ & $>13$ & $\mathrm{~F}$ & $\mathrm{M}$ & Excarvated & DLBC & Subtotal & Chemotherapy \\
\hline 2007 Hirai & 70 & & & $>3$ & & $\mathrm{~L} \sim \mathrm{M}$ & & DLBC & Total & Chemotherapy \\
\hline 2008 Matsunaga & 73 & $4.5 \times 2.0 \mathrm{~cm}$ & $3 \mathrm{~cm}$ & $>3$ & $\mathrm{M}$ & $\mathrm{M}$ & & DLBC & Total & R-CHOP \\
\hline 2008 Our case & 85 & $\begin{array}{l}6.5 \times 6 \mathrm{~cm} \\
9 \times 8.5 \mathrm{~cm}\end{array}$ & $30 \mathrm{~mm}$ & 6 & $\mathrm{~F}$ & $\mathrm{~L}$ & Excarvated & DLBC & Total & \\
\hline
\end{tabular}

CHOP, cyclophosphamide, doxorubicin, vincristine, prednison; DLBC, diffuse large B-cell; DMBC, diffuse medium B-cell; LSG, lymphoma study group classification; MALT, mucosa associated lymphoid tissue; THP-COP, pirarubicin, cyclophosphamide, vincristine, prednisone; VEMP, etoposide, cyclophosphamide, mitoxantrone, prednisone; VEPA, vincristine, cyclophosphamide, prednisolone, adriamycin.

yet no established treatment strategy for gastric malignant lymphoma. Its merits emphasis that outcomes of malignant gastric lymphoma with spontaneous perforation was poor (less than 2 years) compared to those without perforation. ${ }^{3}$ It seems that number of metastases to lymph nodes at the emergency surgery may predict the outcomes. ${ }^{2} 310$ The patient had spontaneous perforation 2 days prior to her scheduled operation in our case; the choice of treatment including surgery should be carefully deliberated.

\section{Learning points}

- Tumours with ulceration to be common in perforation cases.

- Large, ulcerative-type tumours are reportedly more likely to perforate.

- Outcomes of malignant gastric lymphoma with spontaneous perforation were poor (less than 2 years) compared to those without perforation.

- The choice of treatment including surgery should be carefully deliberated.

Competing interests None.

Patient consent Obtained.

\section{REFERENCES}

1. Toyota T, Nichi M. Gastric perforation (in Japanese). Shyujyutsu (Surgery) 1989;43:623-30.

2. Fukuda N, Watanabe J, Yamakawa T, et al. A case of perforation of huge malignant gastric lymphoma. Jpn Clin Surg 1998;59:698-701.

3. Kanzaki M, Yokoyama T, Saito Y, et al. A case of perforated gastric malignant lymphoma (in Japanese). J Tokyo Womens Med Coll 1985;55:1069-73.

4. Mittal B, Wasserman T, Griffith R. Non-Hodgkin's lymphoma of the stomach. Am J Gastroenterol 1983;78:780-7.

5. Taal BG, Burgers JMV, Heerde P, et al. The clinical spectrum and treatment of primary non-Hodgkin's lymphoma of the stomach. Ann Oncol 1993:4:839-46.

6. Law MM, Williams SB, Wong JH. Role of surgery in the management of primary lymphoma of the gastrointestinal tract. J Surg Oncol 1996;61:199-204.

7. Sano R. Classification of malignant gastric lymphoma (in Japanese). Igakusyoin, Tokyo 1987;257-75.

8. Tanaka T, Iwasa M. Haneda H. A case of malignant gastric lymphoma with spontaneous perforation (in Japanese). Nippon Shoukaki Geka(Jpn Gastroenterol Surg) 2007;40:26-9.

9. Mitsunaga A. Malignant lymphoma (in Japanese).In: Takemoto T, Nagasako $\mathrm{K}$, eds. Diagnostic endoscopy textbook|xE2|x91, esopha-stomach.duodenal. 2nd edn. Bunkodo, Tokyo, 2000:208.

10. Aviles A, Nambo MJ, Neri N, et al. The role of surgery in primary gastric lymphoma: results of a controlled clinical trial. Ann Surg 2004:240:44-50.

11. Nakamura S, Matsumoto T, Nakamura S, et al. Treatment and prognosis of primary gastric B-cell lymphoma (in Japanese). Stomach Bowles 2004:39:261-75.

12. Brooks JJ, Enterline HT. Primary gastric lymphomas - a clinicopathologic study of 58 cases with long-term follow up and literature review. Cancer 1983:51:701-11.

13. Dworkin B, Lightdale CJ, Weingrad DN, et al. Primary gastric lymphoma-a review of 50 cases. Dig Dis Sci 1982;27:986-92. 


\section{BMJ Case Reports}

14. Ando $\mathbf{0}$, Sato T, Umeda A, et al. A rare case of gastric malignant lymphoma which was diagnosed due to perforation. J Nihon Univ Med Assoc 1992; 51:1021-4

15. Oda G, Mishima $Y$, Yoshinaga $K$, et al. A case of malignant gastric lymphoma with spontaneous perforation (in Japanese). Jap Clin Surg Med 1987:48:1379

16. Takeda $\mathbf{T}$, Hasumi $\mathrm{T}$, Akiyama $\mathrm{T}$, et al. A case of malignant gastric lymphoma with perforation (in Japanese). Nippon Shoukakibyou(Jpn Gastroenterol disease) 1989;86:148.

17. Yamaguchi $\mathbf{Y}$, Hitamura $\mathrm{H}$, Iwase $\mathbf{M}$, et al. A case of perforated malignant gastric lymphoma (in Japanese). Jap Clin Surg Med 1999;51:2558.

18. Yanagi S, Kouya $\mathrm{K}$, Kudo $\mathrm{Y}$, et al. A case of perforated malignant gastric lymphoma (in Japanese). Donan Med 1992;27: 9-12.

19. Shinjyo H, Tokiwa K, Kure N, et al. A case of paediatric malignant gastric lymphoma with perforation (in Japanese). Paediatric Cancer 1994:31:542.

20. Mori H, Shirai Y, Kamiya T, et al. A case of perforated malignant gastric lymphoma (in Japanese). Jap Abd Emerg Med 1996;16:255.

21. Banya K, Ono S, Ishi S, et al. A study of perforated malignant lymphoma (in Japanese). Chiba Med 1997;49:1186.
22. Ono S, Tanaka T, Yoshino $\mathrm{H}$, et al. A case of perforated malignant gastric lymphoma (in Japanese). Jap Abd Emerg Med 1997;17:710.

23. Yanagisawa S, Tanaka T, Tsuchiya T, et al. Two cases of malignant gastric lymphoma with spontaneous perforation (in Japanese). Jap Clin Surg 1998; 59:586.

24. Hosui S, Senoo T, Mukouyama $H$, et al. A case of perforated malignant gastric lymphoma (in Japanese). Jap Clin Surg 1998;59:2701.

25. Hosino $\mathbf{Y}$, Sato $\mathrm{H}$, Iwagaki $\mathrm{T}$, et al. A case of malignant gastric lymphoma diagnosed by gastric perforation (in Japanese). Jap Clin Surg 2001;62:1593.

26. Mori R, Miura M, Takahashi T, et al. A case of malignant gastric lymphoma with gastric perforation and intestinal obstruction (in Japanese). Jap Clin Surg 2005:66:1903-7.

27. Hirai $\mathbf{E}$, Ide $\mathbf{M}$, Suzuki $\mathrm{S}$, et al. A case of malignant gastric lymphoma with gastric perforation managed by total gastremtomy (in Japanese). Jap Clin Surg 2007:68:935.

28. Yokoyama T, Kawamura T, Matsuda T, et al. A case of rapidly progressed malignant gastric lymphoma with perforation (in Japanese). Jap Clin Surg 2002;63:2830

Copyright 2013 BMJ Publishing Group. All rights reserved. For permission to reuse any of this content visit http://group.bmj.com/group/rights-licensing/permissions.

BMJ Case Report Fellows may re-use this article for personal use and teaching without any further permission.

Please cite this article as follows (you will need to access the article online to obtain the date of publication).

Shimada S, Gen T, Okamoto $\mathrm{H}$. Malignant gastric lymphoma with spontaneous perforation.

BMJ Case Reports 2013;10.1136/bcr.05.2011.4251, Published XXX

Become a Fellow of BMJ Case Reports today and you can:

- Submit as many cases as you like

- Enjoy fast sympathetic peer review and rapid publication of accepted articles

- Access all the published articles

- Re-use any of the published material for personal use and teaching without further permission

For information on Institutional Fellowships contact consortiasales@bmjgroup.com

Visit casereports.bmj.com for more articles like this and to become a Fellow 